\title{
A Nitrile Hydratase with a Wide Substrate Spectrum Produced by a Brevibacterium sp.
}

\author{
By KIEN BUI, HUGUES FRADET, ALAIN ARNAUD* \\ AND PIERRE GALZY \\ Chaire de Génétique et Microbiologie, École Nationale Supérieure Agronomique, Place Viala, \\ 34060 Montpellier Cedex, France
}

(Received 19 May 1983; revised 21 June 1983)

\begin{abstract}
A mutant strain, Brevibacterium 19, defective for the enzyme nitrile hydratase but retaining all the amidase activity of the wild-type Brevibacterium R312, was isolated. This is genetic evidence in favour of the hypothesis that all the nitrile-hydratase activity of the wild-type was due to a single enzyme, the structural gene of which was lost in the mutant strain 19.

The specific activities and $K_{\mathrm{m}}$ of the nitrile hydratase were determined for 12 different substrates. The affinity of the enzyme increased as the number of hydrogen-bonding positions of the substrate increased, and decreased with more spatial crowding of the hydrocarbon chain. The specific activity of the enzyme for a substrate was enhanced by the nucleophilic and hydrophilic properties of the hydrocarbon side chain of that substrate.
\end{abstract}

\section{INTRODUCTION}

The wild-type strain Brevibacterium R312 (Arnaud et al., 1976a,b) was able to hydrolyse all water-soluble nitriles via the activities of its nitrile hydratase (Arnaud et al., 1977) and its amidase (Jallageas et al., 1978a). A mutant strain, Brevibacterium A4, unable to hydrolyse acetamide, was described by Jallageas et al. (1979) and Arnaud et al. (1980). Unlike the wildtype R312 (Arnaud et al., 1976c), this mutant could no longer hydrolyse many amides such as the aliphatic amides, $\alpha$-aminopropionamide, lactamide, benzamide and the $D$ - $\alpha$-aminopropionamides. This strain retained, however, the ability to hydrolyse $\mathrm{L}-\alpha$-aminoamides (KienyL'Homme et al., 1981). The enzyme no longer synthesized by the mutant A4 strain had previously been described and named acetamidase (Jallageas et al., 1978a).

In the present work, we report the isolation of a mutant strain, Brevibacterium 19, which had lost its ability to hydrate nitriles, including cyanide, while retaining its amidase activity. Considering the industrial potential for the use of the nitrile hydratase enzyme (Bui et al., 1982), we also studied the effect of the structure of the substrate nitriles on the activity of hydratation of nitriles by the wild-type Brevibacterium R312. The $K_{\mathrm{m}}$ and $V_{\max }$ of the nitrile hydratase were determined for 12 different substrates.

\section{METHODS}

Bacterial strain. The wild-type strain used was Brevibacterium R312 (Arnaud et al., 1976a, b).

Media. The composition of the basal minimal medium was as previously described (Kieny-L'Homme et al., 1981). Ammonium sulphate $\left(5 \mathrm{~g}^{-1}\right)$ and glucose $\left(10 \mathrm{~g}^{-1}\right)$ were added to the minimal medium. Slant cultures were maintained on YMPG-agar, the composition of which was given by Jallageas et al. (1978a).

Growth. Cultures were grown at $28{ }^{\circ} \mathrm{C}$ in conical flasks filled to $10 \%(\mathrm{v} / \mathrm{v})$ of their capacity and shaken at 80 r.p.m.

Enzyme extraction. Disruption of hacteria by grinding, and preparation of extracts, were performed as previously described (Jallageas et al., 1978a). Determinations of $K_{\mathrm{m}}$ values were performed using the $\mathrm{S}_{2}$ supernatant obtained by centrifugation at $180000 \mathrm{~g}$ for $90 \mathrm{~min}$. 
Protein assay. Proteins were assayed by the biuret method according to Stickland (1951), with bovine serum albumin as standard.

Enzyme assay. Enzyme activity assays for most nitrile or amide substrates were performed by GLC according to the technique of Jallageas $e t$ al. (1978b). Cyanide, $\alpha$-aminonitriles and $\alpha$-hydroxynitriles were determined by the colorimetric technique of Szewczuk (1959) as modified by Buti (1975), Bridi (1980) and L'Homme (1980).

Origin of nitriles and amides used. The $\alpha$-aminonitriles were synthesized according to the classical methods of Marvel \& Brubacker (1948) and Béjaud et al. (1975). All other nitriles and amides used were commercially available.

\section{RESULTS AND DISCUSSION}

\section{Isolation and study of a nitrile hydratase defective mutant}

The isolation of a nitrile hydratase defective mutant was based on the following principle: in the presence of the wild-type, a halogenated nitrile would be hydrated into a halogenated amide, which would then be hydrolysed into a halogenated acid. Such compounds are toxic to some micro-organisms (Apirion, 1965; Hynes \& Pateman, 1970; Clarke \& Tata, 1973). All colonies capable of growing on a solid medium in the presence of such a halogenated nitrile would be potentially nitrile hydratase defective mutants.

Chloroacetonitrile was chosen for our purposes. It is a substrate for the Brevibacterium nitrile hydratase. The toxicity of chloroacetonitrile for the wild-type Brevibacterium R312 was tested using a solid agar medium with acetamide $\left(5 \mathrm{gl}^{-1}\right)$ as a source of carbon and nitrogen. There was no growth of the wild-type with chloroacetonitrile at $0.6 \mathrm{~g} \mathrm{l}^{-1}$ and above.

The isolation scheme is shown in Table 1. The wild-type was grown on minimal medium containing glucose $\left(10 \mathrm{gl}^{-1}\right)$ and acetamide $\left(5 \mathrm{gl}^{-1}\right)$. The cells were then spread on to minimal agar medium containing glucose $\left(10 \mathrm{gl}^{-1}\right)$, acetamide $\left(5 \mathrm{gl}^{-1}\right)$, and chloroacetonitrile $\left(0.6 \mathrm{~g}^{-1}\right)$. All colonies which developed on this medium were selected and maintained on YMPG agar slants. The selected strains were then inoculated into minimal medium containing acetonitrile as sole nitrogen source. No growth was observed for strain 19, obtained without mutagenic treatment, and for six other strains, obtained following treatment with EMS.

The Brevibacterium strain 19 showed the same morphological and biological properties as the wild-type. Its nitrile hydratase activity spectrum was compared with that of the wild-type (Arnaud et al., 1976a,b) for the following compounds: $\mathrm{KCN}$, acetonitrile, propionitrile, $\alpha$-hydroxypropionitrile, $\beta$-hydroxypropionitrile, $\alpha$-aminopropionitrile, $\beta$-aminopropionitrile, acrylonitrile, butyronitrile, isobutyronitrile, valeronitrile, pivalonitrile and benzonitrile. Whole cells and a cell-free preparation of the mutant strain were unable to hydrate the above nitriles, while the amidase activity of the mutant remained identical to that of the wild-type. The mutation was stable for at least 50 generations of vegetative growth.

\section{Determination of $K_{m}$ and $V_{\max }$ values of nitrile hydratase on different substrates}

This general nitrile hydratase enzyme was previously described as acetonitrilase (Arnaud $e t$ al., 1977). Its optimum pH is 7.0 and its optimum temperature is 30 to $35^{\circ} \mathrm{C}$ for acetonitrile. The enzyme is thermolabile, losing all activity on heating at $45^{\circ} \mathrm{C}$ for $5 \mathrm{~min}$. The $K_{\mathrm{m}}$ determined for acetonitrile is $2.5 \times 10^{-2} \mathrm{M}$. The active site of the enzyme contains $-\mathrm{OH},-\mathrm{NH}_{2}$ and $-\mathrm{SH}$ groups. As this enzyme could be used in bioconversion to hydrate many nitriles into amides, its hydratation parameters for 12 different substrates have been determined.

We found during preliminary experiments that the enzyme activity of our cell-free preparation was very high. For some substrates, this preparation had to be diluted up to 100 times for precise kinetic measurements. As genetic results showed that only one enzyme was involved, we did not find it necessary to purify the preparation for the determination of $K_{\mathrm{m}}$ and relative specific activities for different substrates. Only the $V_{\max }$ results would be affected by the relative amount of the hydratase in the extract. Thus all $K_{\mathrm{m}}$ and specific activities were determined using the supernatant following centrifugation at $180000 \mathrm{~g}$ for $90 \mathrm{~min}$.

The $K_{\mathrm{m}}$ and $V_{\max }$ of the nitrile hydratase for different substrates, determined from Lineweaver-Burk plots, are summarized in Table 2. Also included in this table are the results obtained by Bridi (1980) for cyanide and Arnaud et al. (1977) for acetonitrile. The hydratation 
Table 1. Isolation scheme for a nitrile hydratase defective mutant

\begin{tabular}{lcc}
\multicolumn{1}{c}{ Medium } & Wild-type & Mutant \\
$\begin{array}{l}\text { Minimal medium } \\
+ \text { Glucose }+ \text { acetamide } \\
\text { Minimal medium } \\
+ \text { Glucose }+ \text { acetamide } \\
+ \text { Chloroacetonitrile } \rightarrow\end{array}$ & Growth & Growth \\
& Chloroacetamide & Growth \\
$\begin{array}{l}\text { Minimal medium } \\
+ \text { Glucose }+ \text { acetonitrile }\end{array}$ & Chloroacetic acid (toxic) & \\
& Growth & No growth \\
& & (no nitrogen source available)
\end{tabular}

Table 2. $K_{\mathrm{m}}$ and $V_{\max }$ of nitrile hydratase for different substrates

The $K_{\mathrm{m}}$ and $V_{\max }$ values listed in columns 2 and 3 were determined from more than one batch of enzyme preparation. Because of variations in the amount of the hydratase in the different batches, the $V_{\max }$ values sometimes differed. Therefore, the relative specific activities (column 4) were calculated from $V_{\max }$ values determined using the same enzyme preparation for each of the different substrates; the $V_{\max }$ for propionitrile $(100 \%)$ was $30 \mu \mathrm{mol} \mathrm{min}^{-1}$ (mg protein) ${ }^{-1}$.

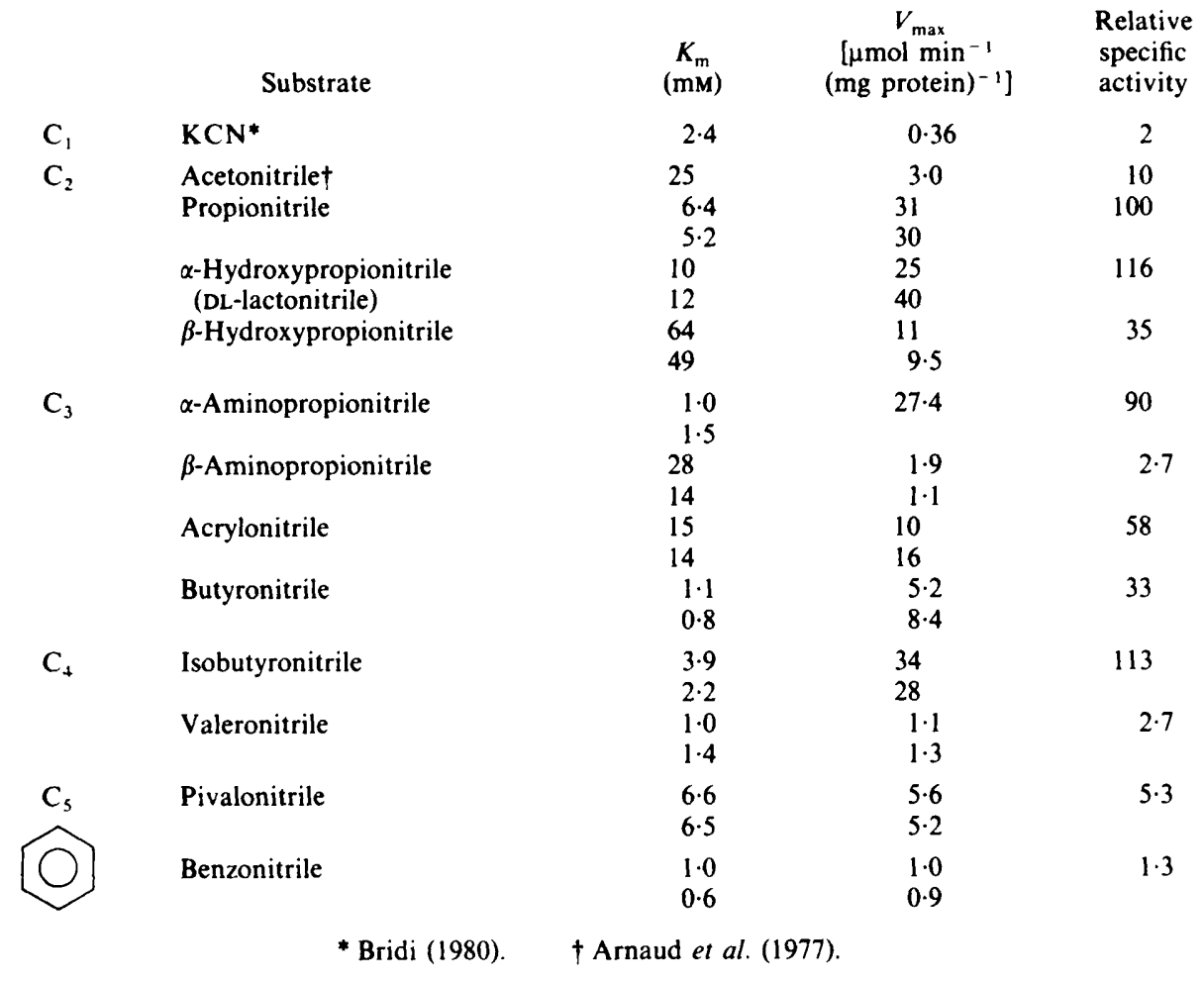

reactions rapidly ceased with lactonitrile, $\alpha$-aminopropionitrile or isobutyronitrile as substrate.

The $K_{\mathrm{m}}$ results for the linear aliphatic nitrile series (i.e. cyanide, acetonitrile, propionitrile, butyronitrile, valeronitrile) showed that this enzyme had the lowest affinity for acetonitrile ( $K_{\mathrm{m}}$ $25 \mathrm{~mm}$ ). The affinity was 10 times greater for cyanide and also increased as the hydrocarbon side chain became longer. Except for cyanide, the length of the hydrocarbon side chain seemed to enhance the affinity of the enzyme for the substrate. This is probably due to the increase of the number of hydrogen-bonding positions between the enzyme and the hydrocarbon side chain.

Considering the substrate series acetonitrile, propionitrile, isobutyronitrile, pivalonitrile, the longer the hydrocarbon chain the lower was the $K_{\mathrm{m}}$ for the substrate. The affinities of the enzyme for propionitrile, isobutyronitrile and pivalonitrile were four to eight times greater than 
for acetonitrile. The methyl groups on the hydrocarbon chain thus increased the affinity of the enzyme for these substrates, probably again due to a greater number of hydrogen bonds which could be established. On the other hand, this increase in affinity was counterbalanced by the spatial crowding effect of the same methyl groups, which decreased the affinity of the enzyme. This was especially apparent for the $K_{\mathrm{m}}$ of pivalonitrile $(6.3 \mathrm{mM})$ and of isobutyronitrile (3.0 mM).

Also, the linear-chained substrates butyronitrile and valeronitrile had $K_{\mathrm{m}}$ values three to six times smaller than their corresponding branched isomers, isobutyronitrile and pivalonitrile. The difference in affinity increased as the number of methyl groups increased. This confirmed the supposition that molecular crowding near the $-\mathrm{C} \equiv \mathrm{N}$ terminal caused a decrease in the affinity of the enzyme for the nitrile substrates. Nitriles having the form $\mathrm{R}-\mathrm{CH}_{2}-\mathrm{C} \equiv \mathrm{N}$ can also temporarily exist in the form $\mathrm{R}-\mathrm{CH}=\mathrm{C}=\mathrm{NH}$ (Allinger et al., 1983); in this form access to the active site of the enzyme would be facilitated.

The $K_{m}$ values for $\alpha$ - and $\beta$-hydroxypropionitrile and $\alpha$-and $\beta$-aminopropionitrile showed that the affinity of the enzyme was 5 to 15 times greater when the amino or the hydroxy group was in the $\alpha$ position as compared to the $\beta$ position. The propionitrile derivatives with an amino group had $K_{\mathrm{m}}$ values five to eight times smaller than those with a hydroxy group substituted at the same position, $\alpha$ or $\beta$. These results agree with the reports by Arnaud et al. (1977) and L'Homme (1980) that there are $-\mathrm{OH}$ and $-\mathrm{NH}_{2}$ groups at the active site of this enzyme, and with the hypothesis that the affinity of the enzyme increases as more hydrogen bonds are established between the enzyme and its substrates.

It was noteworthy that the $K_{\mathrm{m}}$ for benzonitrile was similar to those for butyronitrile and valeronitrile, despite its aromatic ring. This was probably due to the flatness of this molecule, which permitted a closer contact with the enzyme as compared to the spatial interference of the methyl groups of the branched aliphatic nitriles.

\section{Determination of relative specific activities}

In order to obtain specific activities comparable to each other, the same enzyme preparation was used to determine the $V_{\max }$ of different substrates and of propionitrile in the same experiment. The results are given in Table 2, where the relative specific activities are expressed as the percentage of that obtained for propionitrile, $30 \mu \mathrm{mol} \mathrm{min}^{-1}\left(\mathrm{mg}\right.$ protein) ${ }^{-1}$.

Except for lactonitrile ( $\alpha$-hydroxypropionitrile) and isobutyronitrile, which will be discussed further, the greatest specific activity was found for propionitrile. The specific activities of the branched substrates isobutyronitrile and pivalonitrile were greater than those of their respective isomers, butyronitrile and valeronitrile. The hydrocarbon side chains of these branched substrates were more nucleophilic than their isomers.

In the nitrile substrate class with three carbon atoms in each molecule, the presence of a hydroxy group enhanced the hydratation rate compared to that observed with an amino group substituted at the same position. Also, substrates with an active group substituted at the $\beta$ position had smaller specific activities than those with the same active group substituted at the $\alpha$ position. The specific activity obtained for acrylonitrile, with its double bond, was very close to that for $\beta$-hydroxypropionitrile. These results suggest that a hydrophilic hydrocarbon side chain, especially at the $\alpha$ position, enhances hydratation catalysed by this enzyme.

The specific activity determined for benzonitrile was smaller than those found for the aliphatic nitriles used in this work. However, the activity was strong enough to be easily measured, confirming the reports of Arnaud et al. $(1976 a, b)$ that this enzyme has a wide activity spectrum, including aromatic as well as aliphatic nitriles.

The above results agree with the reaction mechanism proposed by Asano et al. (1982) for a nitrile hydratase:

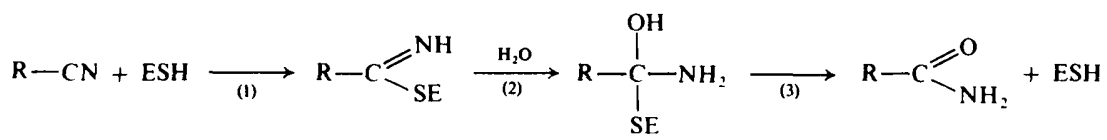


(1) The thiol enzyme (ESH) initiates a nucleophilic attack on the nitrile substrate carbon and yields an imino-enzyme complex. An electrophilic hydrocarbon side chain, $\mathbf{R}-$, would tend to draw electrons away from the triple bond of the nitrile substrate and slows down this reaction step.

(2) The imino-enzyme complex is hydrated, yielding the intermediary (I). This step is favoured by the presence of a hydrophilic hydrocarbon side chain, $\mathbf{R}-$, which would facilitate the approach of a water molecule required for the reaction.

(3) The intermediary (I) decomposes yielding an amide product and the original thiol enzyme.

The specific activity measured for each substrate resulted from the combined contrary effects of their electrophilic and hydrophilic properties on the reaction rate.

\section{REFERENCES}

Allinger, N. L., Cava, M. P., de Jongh, D. C. Hohnson, C. R., Lebel, N. A. \& Stevens, C. L. (1983). Chimie Organique, vol. I: Structure. Paris: McGraw-Hill.

ApIRION, D. (1965). The two-way selection of mutants and revertants in respect of acetate utilization and resistance to fluoroacetate in Aspergillus nidulans. Genetical Research 6, 317-329.

Arnaud, A., Galzy, P. \& Jallageas, J. C. (1976a). Remarques sur lactivité nitrilasique de quelques bactéries. Comptes rendus de l'Académie des sciences 283, 571-573.

Arnaud, A., Galzy, P. \& Jallageas, J. C. (1976b). Étude de l'activité nitrilasique de quelques bactéries. Revue des fermentations et des industries alimentaires 31, 39-44.

Arnaud, A., Galzy, P. \& Jallageas, J. C. (1976c) Amidase activity of some bacteria. Folia microbiologica 21, 178-185.

Arnaud, A., Jallageas, J. C. \& Galzy, P. (1977). Étude de l'acétonitrilase d'une souche de Brevibacterium. Agricultural and Biological Chemistry' 41, 21832191 .

Arnaud, A., Galzy, P. \& Jallageas, J. C. (1980). Production d'acides $\alpha$-aminés stéréospécifiques par hydrolyse biologique d' $\alpha$-aminonitriles racémiques. Bulletin de la Société chimique de France 2, 8790.

Béjaud, M., Mion, L., Taillades, J. \& Commeyras, A. (1975). Systèmes de Strecker et apparentés. Tetrahedron 31, 403-408.

BRIDI, K. (1980). Contribution à l'étude du métabolisme du cyanure chez une souche de Brevibacterium. Rapport de DEA Sciences Alimentaires, Unitersité de Montpellier.

Bui, K., Arnaud, A. \& Galzy, P. (1982). A new method to prepare amides by bioconversion of corresponding nitriles. Enzyme and Microbial Technology 4, 195-197.

Butı, R. (1975). Contribution à l'étude de l'hydrolyse des $\alpha$-aminonitriles. I-En solution aqueuse basique. II -
Par des bactéries à activité nitrilasique. Thèse de 3éme cycle, Université des Sciences et Techniques du Languedoc, Montpellier.

ClaRKe P. H. \& TATA, R. (1973). Isolation of amidase negative mutants of Pseudomonas aeruginosa by a positive selection method using an acetamide analogue. Journal of General Microbiology 75, 231-234.

Hynes, M. J. \& Pateman, J. A. J. (1970). The genetic analysis of regulation of amidase synthesis in Aspergillus nidulans. II. Mutants resistant to fluoroacetamide. Molecular and General Genetics 108, 107 116.

Jallageas, J. C., Arnaud, A. \& Galzy, P. (1978a). Étude de l'acétamidase d'une souche de Brevibacterium. Journal of General and Applied Microbiology 24, 103-114.

Jallageas, J. C., Arnaud, A. \& Galzy, P. (1978b). Application de la chromatographie en phase gazeuse à l'étude des nitrilases et amidases. Journal of Chromatography 116, 181-187.

Jallageas, J. C., Arnaud, A. \& Galzy, P. (1979). Remarques sur le spectre d'activité amidasique d'un mutant de Brevibacterium. Comptes rendus de l'Académie des sciences 288, 655-658.

Kieny-L'Homme, M. P., Arnaud, A. \& Galz.y, P. (1981). Étude d'une $L-\alpha$-aminoamidase particulaire de Brevibacterium sp. en vue de l'obtention d'acides $\alpha$-aminés optiquement actifs. Journal of General and Applied Microbiology 27, 307-325.

L'Hoмme, C. (1980). Remarques sur l'activité nitrilasique de dicerses souches bactériennes. Thèse de Docteur Ingénieur, Université des Sciences et Techniques du Languedoc, Montpellier.

MaRVel, C. S. \& Brubacker, M. M. (1948). Organic Synthesis, vol. 1. New York: John Wiley.

StickLAND, L. H. (1981). The determination of small quantities of bacteria by means of the biuret reaction. Journal of General Microbiology' 5, 698-703.

Szewczuk, A. (1959). Méthode colorimétrique pour la détermination des $\alpha$-aminonitriles. Chemia analityczna 4, 65-70. 